\title{
The Perceived Impact of Online Student Evaluation to the Performance Among Faculty from PUP Branches and Campuses: Basis for Policy Review and Implementation
}

\author{
Jerielyn V. Reyes ${ }^{1}$, Arapia C. Ariraya², Reynaldo A. Guerzon¹, and Aris L. Solis ${ }^{1}$ \\ ${ }^{1}$ PUP College of Communication DAPR \\ ${ }^{2}$ PUP College of Communication DBC
}

\section{Abstract}

The study aims to determine the perception of the PUP faculty from branches and campuses about the student's online evaluation and investigate the implication of results to their performance as teacher in higher education institution. Descriptive and inferential statistics were used to interpret data. The researchers utilized

Corresponding Author: Jerielyn V. Reyes

jerielyn_reyeso4@yahoo.com

Received: 23 April 2018

Accepted: 8 May 2018

Published: 4 June 2018

Publishing services provided by Knowledge $\mathrm{E}$

(c) Jerielyn V. Reyes et al. This article is distributed under the terms of the Creative Commons Attribution License, which permits unrestricted use and redistribution provided that the original author and source are credited.

Selection and Peer-review under the responsibility of the IRCHE 2017 Conference Committee. primary data through self-administered survey questionnaire and secondary data. Findings revealed that in general, the faculty find the content in four areas of evaluation namely: commitment, knowledge of the subject, teaching for independent learning and management, highly acceptable. They agree with the rating scale and its equivalent description. The perceived performance of the faculty in four areas showed improvement. The faculty recognized that their personal and social development had improved. When respondents were grouped according to highest educational attainment, significant difference was observed on commitment area. Majority of the faculty felt that students do not fully understand the content of the evaluation instrument, and worst, they use the evaluation as the chance to get even with the professors they dislike. It is recommended to simplify the statements in the instrument. To substantiate the comments and maintain objectivity, the researchers recommend inclusion of students' personal assessment regarding learning. To further improve the performance of the faculty, deans and chairpersons may identify the administrative concerns of their faculty and identify areas that need training, retraining, coaching, and/or policy revision.

Keywords: effective teaching, instruction, faculty performance, student evaluation 


\section{Introduction}

Effective teaching matters in preparing college students to become productive and competent members in the society. To ensure that there is quality instruction in higher education institutions, regular faculty evaluation by the students is done to measure effectiveness of classroom teaching experience, improve performance, and document accountability. This serves as a form of summative and formative evaluation (Kelly, 2012). Students are capable of making valid and reliable judgements about classroom teaching performance given the fact that they have longer exposure to instructional experience. Coe, Aloisi, Higgins, \& Major (2014) expressed that student ratings are valid, reliable, and cost-effective, relates to future achievement, valuable for teacher formative feedback, and require minimal training. (Frase, English, \& Jr. (1995) stated that people want to know how they are doing and how to improve. They can do so if given accurate feedback, constructive ideas, and resource assistance. The performance reviews should be used for information and encouragement. According to O'Kell (2017) the best evaluations are those that identify problems where they exist, but also the ways and means of encouragement that can lead to improvement.

Being evaluated by students give educators mixed feelings. Students feedback can provide enormous help for teacher's self-awareness; insights on how to improve their teaching style. But, there are instances where students use evaluation to get even with the professors whose teaching and discipline styles they dislike. The evaluation could have a lasting impact to professors' personal and professional development. Student evaluation is no doubt had impact and made difference on teaching which is generally beneficial. Murray (2005) observed that over the past 30-40 years, college teaching has improved and is partly due to student evaluation. However, the possibility remains that student evaluation of teaching does cause grade inflation and lowering of academic standards. Stark \& Freishtat (2014) also observed the same as pedagogical advancements could be suppressed by down grading the course content if teachers are motivated to receive high ratings from students.

Taylor \& Tyler (2012) said that a well-structured evaluation system could enhance teacher effectiveness and performance evaluation can be an effective form of teacher professional development. The focus should be on the development rather than a tool in rewards-and-punishment incentive scheme. A good teacher evaluation according to Peterson (1995) must be technically sophisticated that it covers the full range of teacher types and duties. It was suggested by Yew, Kanaki, Manickam, Jen, \& Hoay 
(2015) that institution of learning has to develop its own instrument according to the institutional needs aligned with good practices in teaching and learning

Important decisions like merit reviews, tenure and promotions are based in part on these evaluations. Online faculty evaluation by the students is being used in the PUP system and this study considered its Luzon branches and campuses. The Polytechnic University of the Philippines (PUP) adapted the NBC 416 Instruction areas which covers commitment, knowledge of subject, teaching for independent learning and management of learning for the evaluation process. This evaluation by the students is intended to promote the quality of instruction; a part in the development of a culture of excellence. The evaluation by students comprises 30\% the total QCE point of the faculty.

The commitment area pertains to a deep sense of responsibility in rendering service for the well-being of students as well as the advancement of the discipline. A committed teacher always makes every effort to advance student's professional competence by providing them a quality learning environment and endeavors their students to be well-educated in their community.

Knowledge of subject gauges the expertise of the faculty within the chosen field or discipline. Coe et al (2014) stated that the most effective teachers have deep knowledge of the subjects they teach, and when teachers' knowledge falls below a certain level it is a significant impediment to students learning.

The teaching for independent learning has to do with enabling students to maximize their learning potentials. Alsharif \& Qi (2014) found that instructor's enthusiasm has very high correlation with student intrinsic motivation and vitality. The desire to learn can be infectious.

Management of learning is where faculty member succeeds in creating a conducive learning environment while guiding, monitoring and evaluating student learning. Merillat \& Scheibmeir (2016) analysis showed a positive correlation between an instructor's desire to learn more about teaching and learning best practices and students' perception of progress toward objectives, excellence of teacher, and the overall course score.

It takes a lot of effort to become effective teacher. Chianese (2015) said that teachers must not lose their enthusiasm and they need to assess their learning instrument and methodologies could help them in their professional development. Buskist, Keeley, \& Irons (2006) stated that those faculty who are taking teaching seriously are very reflective on how they can become more effective teacher leading them to improve teaching practices and student learning. 
In the assessment of performance, the study is anchored in the self-determination theory initially developed by Edward L. Deci and Richard M. Ryan. Self-Determination Theory or simply SDT states that humans have inherent growth tendencies as seen in their consistent effort, agency and commitment. The social and cultural factors could facilitate or undermine the quality of performance with sense of volition and initiative. The three innate needs: competence, relatedness and autonomy when satisfied will motivate an individual to perform at the optimal function and growth but when thwarted within social context will have a devastating impact. Both Peterson (1995) and OSBA (n.d.) acknowledged that intrinsic rewards are deemed more meaningful in motivating teachers in improving their crafts such as self-respect, responsibility and accomplishments than extrinsic rewards. Therefore, a meaningful evaluation should be used to uplift the intrinsic needs of faculty, thereby, motivating them to improve their discipline.

Frase et al. (1995) recognized work context and work content as factors that affect the ability of teachers to work effectively. Work context pertains to physiological needs, instructional materials and working condition, the basic needs that must be satisfied to achieve best performance. Work content factors are the intrinsic rewards for the work itself. These include opportunities for professional development, achievement, challenges in carrying out tasks, additional responsibilities and authority. Evaluation provides feedback and recognition that motivates teachers to improve and grow in their profession.

\section{Objectives of the Study}

In this paper, the researchers aim to determine the perception of PUP faculty from branches and campuses about the student's online faculty evaluation and investigate the implication of results to higher education institution. It tests the significant difference on improvement according to profile of the faculty and the significance of the factors that affect their performance as well as their personal assessment for improvement.

\section{Materials and Methods}

This study used descriptive research method designed to gather information from the faculty of PUP branches and campuses on their perception about the students' online faculty evaluation and its impact to their performance. Inferential statistics was 
also used to interpret data. It utilized non-probability sampling through convenience sampling technique where availability of respondents was considered.

The researcher surveyed 218 faculty members from the 12 PUP branches and campuses that are currently using online faculty evaluation. Ten (10) from Bansud, 24 from Bataan, 10 from Cabiao, 25 from Lopez, 13 from Paranaque, 12 from Pulilan, 16 from Quezon City, 20 from Ragay, 12 from Sablayan, 21 from Sta. Rosa, 26 from Sto. Tomas, and 29 from Taguig. All faculty respondents were considered regardless of status, rank, position and designation.

To obtain primary data, the researchers formulated an instrument utilized for the study. The research instrument underwent several revisions and was validated by experts in education and in guidance and counselling. It was pre-tested to 30 respondents from the main campus and had been through Cronbach's alpha reliability test which garnered.095 alpha coefficient result.

The survey instrument contained three parts. The first part was the respondent's profile. A checklist was provided. The second and third are the assessment parts, a five (5) point Likert scale was used to measure the agreement or disagreement of the respondents' answer to different variables. The second part is the acceptability of the student evaluation instrument in the personal assessment of the faculty. The third part is the determination of impact of faculty evaluation.

The study also solicited opinion through the open-ended questions in the survey instrument regarding the evaluation process and comments on the items that need inclusion or deletion.

The gathered data were computed and analyzed using four statistical methods: (1) Frequency and Percentage, (2) Weighted Mean, (3) Analysis of Variance (ANOVA)

\section{Results and Discussion}

The faculty demographic profile revealed that there was almost equal representation between male (45.87\%) and female (51.83\%) academic staff from PuP branches and campuses and is dominated by married faculty members (57.34\%). Their ages range between $31-40$ years old (32.57\%) which means that the pool of faculty are considered young and matured. The demographic profile of the faculty from PUP branches and campuses could mean that they have the ideal set of academic staff based on demographic characteristics that could greatly impact the performance of their students.

The faculty academic background showed that members from PUP branches and campuses are primarily with part-time status and instructor rank. Thirty-three $33 \%$ 
( $n=72$ ) have been faculty for 5-10 years, a young group, considering that most of the campuses were established barely a couple of years ago. Majority of the faculty, $54.13 \%(n=118)$ belong to purely faculty designation, and $34.4 \%(n=75)$ have been in their current position for 2-5 years.

The influx of students to state colleges and universities and the placement of faculty members to administrative positions compelled the institutions to hire faculty through contracts, job orders and emergency instructor on a part-time basis.

With regards the highest educational attainment, $43.12 \%(n=94)$ of the faculty have Master's units and only 28.90\% ( $n=63$ ) completed Master's degree. The finding shows that most of faculty from the PUP branches and campuses are pursuing master's degree while teaching to justify their presence in the academe. Only 9.63\% ( $n=21)$ has doctoral units; $8.26 \%(n=18)$ finished doctoral degree while $8.26 \%(n=18)$ has bachelor's degree. A small percentage, $1.83 \%(n=4)$ has no response.

TABLE 1: Agreement on the Acceptability of Rating Bracket and its Descriptor.

Appropriateness of rating
used
Outstanding is equivalent
to above $91-100 \%$
Very Satisfactory is
equivalent to above 71
-90.99\%
Satisfactory is equivalent
to $51-70.99 \%$
Fair is equivalent to above
$31-50.99 \%$
Poor is equivalent to
$20-30.99 \%$
Overall Weighted Mean

\begin{tabular}{|c|}
\hline Weighted Mean \\
\hline 4.38 \\
\hline 4.17 \\
\hline 4.16 \\
\hline 4.23 \\
\hline 4.22 \\
\hline 4.23 \\
\hline
\end{tabular}

Table 1 shows the agreement or disagreement on the acceptability of the content of faculty evaluation as to the rating scale and its equivalent description and all the items in the four areas of evaluation. It revealed that outstanding bracket of $91-100 \%$ was highly acceptable for faculty with a WM of 4.38 , while all the other category was deemed acceptable with WM of 4.17. Highly acceptable is with WM of 4.3 to 5 ; acceptable WM of 3.5 to 4.2; somewhat acceptable, WM of 2.7 to 3.4; least acceptable 1.9 to 2.6, and not acceptable with WM of 1 to 1.8. The overall WM for the appropriateness of the bracket of the ratings is 4.23 . The respondents agreed that the contents of all the four areas in the evaluation instruments are acceptable with an overall WM of 4.23. 
TABLE 2: Applicability of the Content of Evaluation Instrument to the Discipline.

\begin{tabular}{l|c|c|}
\hline Areas & Mean & Verbal Interpretation \\
\hline $\begin{array}{l}\text { Commitment } \\
\text { Knowledge of subject }\end{array}$ & 4.42 & Highly Applicable \\
\hline $\begin{array}{l}\text { Teaching for independent } \\
\text { learning }\end{array}$ & 4.56 & Highly Applicable \\
\hline $\begin{array}{l}\text { Management of learning } \\
\text { Maghly Applicable }\end{array}$ & Highly Applicable \\
\hline
\end{tabular}

Table 2 shows the applicability of the content of evaluation instrument to the discipline. The commitment area garnered an overall WM of 4.42, knowledge of the subject area yielded an overall WM of 4.56 , teaching for independent learning had an overall WM of 4.52, and the management of learning yielded, with WM 4.35. All were verbally interpreted as highly acceptable.

This generally showed that faculty from PuP branches and campuses find the evaluation tool applicable to their discipline or the subjects they are teaching. The agreement of the faculty with the survey instrument indicated that there is no question with the rating and the content in the evaluation. The validity of the process is dependent on how faculty perceived the properties of the evaluation process because motivation to improve comes from the confidence in the system.

This clearly manifests that adapting NBC 461 of instruction is a sound decision for PUP administration. These four areas which are determined in NBC 461 are generally applicable to all disciplines in the higher education.

Table 3 shows how the result of evaluation can improve instruction and commitment of faculty. The overall weighted mean of 4.13 indicated that the commitment of faculty improved. Being sensitive to student's ability had the highest weighted mean of 4.18 while being conscious of grooming had the lowest at 4.05 WM. Having well prepared lesson got 4.17 WM, keeping accurate record, 4.16 WM; availability to student and prompt submission both yielded 4.14 WM, and coming to class regularly with 4.11 WM.

Table 4 shows that knowledge of the subject yielded an overall weighted mean of 4.17. Mastery the subject had the highest weighted mean of 4.20 . All the other variables gained almost similar weighted mean with had improved verbal interpretation. This practically shows that evaluation inspires the faculty to upgrade their scholastic abilities and level up the discipline; expertise that could improve students' academic performance. 
TABLE 3: Instructional Improvement and Commitment of Faculty.

\begin{tabular}{|c|c|c|}
\hline Commitment & Weighted Mean & Verbal Interpretation \\
\hline $\begin{array}{l}\text { Faculty evaluation results } \\
\text { help me become sensitive } \\
\text { to students' abilities }\end{array}$ & 4.18 & Had improved \\
\hline $\begin{array}{l}\text { Faculty evaluation results } \\
\text { make me available for } \\
\text { students }\end{array}$ & 4.14 & Had improved \\
\hline $\begin{array}{l}\text { Faculty evaluation results } \\
\text { motivate me to regularly } \\
\text { come to class }\end{array}$ & 4.11 & Had improved \\
\hline $\begin{array}{l}\text { Faculty evaluation results } \\
\text { make me conscious of my } \\
\text { grooming }\end{array}$ & 4.05 & Had improved \\
\hline $\begin{array}{l}\text { Faculty evaluation results } \\
\text { inspire me to have } \\
\text { well-prepared lessons }\end{array}$ & 4.17 & Had improved \\
\hline $\begin{array}{l}\text { Faculty evaluation results } \\
\text { impel me to keep accurate } \\
\text { records of students }\end{array}$ & 4.16 & Had improved \\
\hline $\begin{array}{l}\text { Faculty evaluation results } \\
\text { prompt me to submit } \\
\text { documents on time }\end{array}$ & 4.14 & Had improved \\
\hline Overall Weighted Mean & 4.13 & Had improved \\
\hline
\end{tabular}

Table 5 shows that faculty improves instruction for more independent learning. That as a result of evaluation, instruction for more independent learning improved with an overall weighted mean of 4.13. Enhancing the strategies for interactive discussions got the highest weighted mean of 4.15 . Enriching the approach in making students accountable for their performance had 4.13 WM, while recognizing student's performance and the desire to encourage students to learn more than what is required, both yielded $4.11 \mathrm{WM}$. This may mean that student evaluation had influenced the faculty to improve their ability in organizing teaching-learning processes that could enhance the learning potentials of students.

Table 6 shows how instruction improved the faculty's management of student learning. The faculty recognized that instruction toward management of student learning had improved with an overall weighted mean of 4.08 . Designing and implementing better learning condition for healthy exchange and confrontations garnered the highest weighted mean of 4.11. Structuring or re-structuring learning and teaching context to attain collective learning objectives had WM 4.09, while creating opportunities for intensive and extensive contributions of students in class activities got WM 4.08. Using 
TABLE 4: Instruction Improvement Based on Knowledge of Subject of Faculty.

Knowledge of Subject
Faculty evaluation results
encourage me to master
my subject
Faculty evaluation results
inspire me to draw and
share information on the
state-of-the-art theories
and practices
Faculty evaluation results
interest me to integrate
subject into practical
circumstances
Faculty evaluation results
guide me to have a clear
learning intent; relate
topics to relevant current
issues
Faculty evaluation results
help me demonstrate up to
date knowledge.
Overall Weighted Mean

TABLE 5: Instruction Improvement on Teaching for Independent Learning.

\section{Teaching for Independent Learning}

Faculty evaluation results enhance my strategies for interactive discussion

Faculty evaluation results help me recognize students' performance

Faculty evaluation results enrich my approach in making students accountable to their performance

Faculty evaluation results increase my intent to level up students learning potentials

Overall Weighted Mean

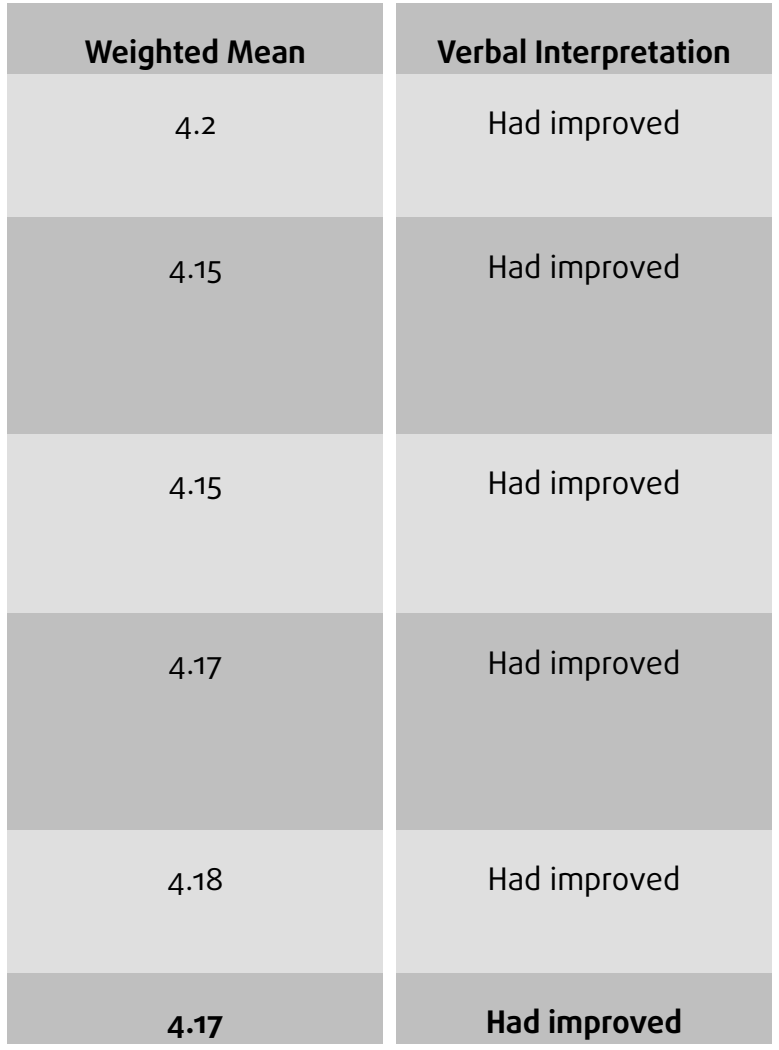

Verbal Interpretation

Had improved

Had improved

\begin{tabular}{|c|c|}
\hline Weighted Mean & Verbal Interpretation \\
\hline 4.15 & Had improved \\
\hline 4.11 & Had improved \\
\hline 4.13 & Had improved \\
\hline 4.11 & \\
\hline 4.13 & Had improved \\
\hline & \\
\hline
\end{tabular}

exceptional instructional materials to reinforce learning process got the lowest WM of 4.08. It could be deduced from the findings that student evaluation imbued the faculty 
TABLE 6: Instruction Improvement on Management of Learning.

\begin{tabular}{|c|c|c|}
\hline Management of Learning & Weighted Mean & Verbal Interpretation \\
\hline $\begin{array}{l}\text { Faculty evaluation results } \\
\text { inspire me to design and } \\
\text { implement better learning } \\
\text { condition for healthy } \\
\text { exchange and } \\
\text { confrontations }\end{array}$ & 4.11 & Had improved \\
\hline $\begin{array}{l}\text { Faculty evaluation results } \\
\text { help me expand creating } \\
\text { opportunities for intensive } \\
\text { and extensive contribution } \\
\text { of students in the class } \\
\text { activities }\end{array}$ & 4.08 & Had improved \\
\hline $\begin{array}{l}\text { Faculty evaluation results } \\
\text { help me develop a better } \\
\text { structure/re-structures } \\
\text { learning and teaching } \\
\text { context to attain collective } \\
\text { learning objectives }\end{array}$ & 4.09 & Had improved \\
\hline $\begin{array}{l}\text { Faculty evaluation results } \\
\text { move me to use } \\
\text { exceptional instructional } \\
\text { materials to reinforce } \\
\text { learning process. }\end{array}$ & 4.03 & Had improved \\
\hline Overall Weighted Mean & 4.08 & Had improved \\
\hline
\end{tabular}

to improve instruction and provide opportunities for an engaging learning environment.

Table 7 shows the impact of evaluation results to faculty's personal growth and social development. The evaluation helped the faculty improve as a person with an overall WM of 4.11. The item on reflecting the specific areas of academic strengths and weaknesses gained $4.21 \mathrm{WM}$. The evaluation results also made the faculty more reflective on their effectiveness across varying students' characteristics with WM of 4.15. Likewise, the evaluation gave the faculty an in-depth understanding of the teaching profession with WM of 4.13 ; the perception of the faculty on teaching practice, WM of 4.10 , as well as the attitude towards teaching with WM of 4.09 . Both the motivation in developing written growth plan and monitoring progress relative to professional growth garnered 4.06 WM. The faculty had become more reflective on the effectiveness as a person and as a professional.

Tables 3 to 7 shows how instruction areas, personal and social development of faculty improved. The study revealed that the performance of faculty had improved in all four areas of instruction. The evaluation made faculty more dedicated and responsible 
TABLE 7: Improvement on Personal and Social Development.

\begin{tabular}{|c|c|c|}
\hline Personal Development & Weighted Mean & Verbal Interpretation \\
\hline $\begin{array}{l}\text { Evaluation results help me } \\
\text { think of the specific areas } \\
\text { of my academic strengths } \\
\text { and weaknesses }\end{array}$ & 4.21 & Had improved \\
\hline $\begin{array}{l}\text { Evaluation results make } \\
\text { me reflect on my lesson } \\
\text { effectiveness, specific } \\
\text { teaching strategies, and } \\
\text { behaviors across different } \\
\text { categories of students }\end{array}$ & 4.15 & Had improved \\
\hline $\begin{array}{l}\text { Evaluation results motivate } \\
\text { me to develop a written } \\
\text { growth and development } \\
\text { plan }\end{array}$ & 4.06 & Had improved \\
\hline $\begin{array}{l}\text { Evaluation results inspire } \\
\text { me to monitor my progress } \\
\text { relative to the professional } \\
\text { growth plan }\end{array}$ & 4.06 & Had improved \\
\hline $\begin{array}{l}\text { Evaluation results help me } \\
\text { understand profoundly my } \\
\text { teaching profession }\end{array}$ & 4.13 & Had improved \\
\hline $\begin{array}{l}\text { Evaluation results help me } \\
\text { transform my attitude } \\
\text { towards teaching } \\
\text { profession }\end{array}$ & 4.09 & Had improved \\
\hline $\begin{array}{l}\text { Evaluation results allow } \\
\text { me to change my } \\
\text { perception about teaching } \\
\text { practice }\end{array}$ & 4.1 & Had improved \\
\hline Overall Weighted Mean & 4.11 & Had improved \\
\hline & Social Developmen & \\
\hline $\begin{array}{l}\text { Faculty evaluation results } \\
\text { inspire me to mentor other } \\
\text { teachers and share ideas } \\
\text { and strategies }\end{array}$ & 3.91 & Had improved \\
\hline $\begin{array}{l}\text { Faculty evaluation results } \\
\text { encourage me to adhere to } \\
\text { school rules and } \\
\text { regulations }\end{array}$ & 4.02 & Had improved \\
\hline $\begin{array}{l}\text { Faculty evaluation results } \\
\text { influence me to participate } \\
\text { in school initiatives. }\end{array}$ & 4.01 & Had improved \\
\hline Overall Weighted Mean & 3.98 & Had improved \\
\hline
\end{tabular}

in rendering professional service to the students and the advancement of the discipline. This manifest that it inspires the faculty to upgrade their scholastic abilities and 
level up the discipline; expertise that could improve students' academic performance. Student evaluation had influenced the faculty to improve their ability in organizing teaching-learning processes that could enhance the learning potentials of students. This imbued the faculty to improve instruction and provide opportunities for an engaging learning environment.

It could be gleaned that faculty took the result of evaluation seriously. The faculty became more reflective toward their effectiveness and efficiency as teacher. The results showed that evaluation had a positive impact on them and realized the formative purpose of evaluation.

TABLE 8: Significant Different of Improvement as per Educational Attainment.

\begin{tabular}{|c|c|c|c|c|}
\hline Indicator & $\begin{array}{l}\text { Highest } \\
\text { Educational } \\
\text { Attainment }\end{array}$ & Mean & F-value & p-value \\
\hline \multirow[t]{5}{*}{$\begin{array}{l}\text { Improvement on } \\
\text { Commitment }\end{array}$} & $\begin{array}{l}\text { With Bachelor's } \\
\text { Degree }\end{array}$ & 4.35 & 2.485 & 0.045 \\
\hline & $\begin{array}{l}\text { With Masters } \\
\text { Units }\end{array}$ & 4.25 & & \\
\hline & $\begin{array}{l}\text { With Master's } \\
\text { Degree }\end{array}$ & 4.06 & & \\
\hline & $\begin{array}{c}\text { With Doctoral } \\
\text { Units }\end{array}$ & 3.74 & & \\
\hline & $\begin{array}{l}\text { With Doctoral } \\
\text { Degree }\end{array}$ & 4.17 & & \\
\hline \multirow{5}{*}{$\begin{array}{l}\text { Improvement on } \\
\text { Knowledge of } \\
\text { Subject }\end{array}$} & $\begin{array}{c}\text { With Bachelor's } \\
\text { Degree }\end{array}$ & 4.07 & 2.075 & 0.085 \\
\hline & $\begin{array}{l}\text { With Masters } \\
\text { Units }\end{array}$ & 4.32 & & \\
\hline & Master's Degree & 4.1 & & \\
\hline & $\begin{array}{l}\text { With Doctoral } \\
\text { Units }\end{array}$ & 3.82 & & \\
\hline & $\begin{array}{l}\text { With Doctoral } \\
\text { Degree }\end{array}$ & 4.11 & & \\
\hline \multirow{5}{*}{$\begin{array}{l}\text { Improvement on } \\
\text { Teaching for } \\
\text { Independent } \\
\text { Learning }\end{array}$} & $\begin{array}{l}\text { With Bachelor's } \\
\text { Degree }\end{array}$ & 3.99 & 1.757 & 0.139 \\
\hline & $\begin{array}{c}\text { With Masters } \\
\text { Units }\end{array}$ & 4.28 & & \\
\hline & $\begin{array}{l}\text { With Master's } \\
\text { Degree }\end{array}$ & 4.07 & & \\
\hline & $\begin{array}{l}\text { With Doctoral } \\
\text { Units }\end{array}$ & 3.8 & & \\
\hline & $\begin{array}{l}\text { With Doctoral } \\
\text { Degree }\end{array}$ & 4.09 & & \\
\hline
\end{tabular}




\begin{tabular}{|c|c|c|c|c|}
\hline Indicator & $\begin{array}{c}\text { Highest } \\
\text { Educational } \\
\text { Attainment }\end{array}$ & Mean & F-value & p-value \\
\hline \multirow{5}{*}{$\begin{array}{l}\text { Improvement on } \\
\text { Management of } \\
\text { Learning }\end{array}$} & $\begin{array}{c}\text { With Bachelor's } \\
\text { Degree }\end{array}$ & 3.93 & 1.091 & 0.362 \\
\hline & $\begin{array}{c}\text { With Masters } \\
\text { Units }\end{array}$ & 4.19 & & \\
\hline & $\begin{array}{l}\text { With Master's } \\
\text { Degree }\end{array}$ & 4.06 & & \\
\hline & $\begin{array}{l}\text { With Doctoral } \\
\text { Units }\end{array}$ & 3.83 & & \\
\hline & $\begin{array}{l}\text { With Doctoral } \\
\text { Degree }\end{array}$ & 3.98 & & \\
\hline \multirow[t]{5}{*}{$\begin{array}{l}\text { Personal } \\
\text { Development }\end{array}$} & $\begin{array}{c}\text { With Bachelor's } \\
\text { Degree }\end{array}$ & 4.01 & 1.917 & 0.109 \\
\hline & $\begin{array}{l}\text { With Masters } \\
\text { Units }\end{array}$ & 4.24 & & \\
\hline & $\begin{array}{l}\text { With Master's } \\
\text { Degree }\end{array}$ & 4.14 & & \\
\hline & $\begin{array}{l}\text { With Doctoral } \\
\text { Units }\end{array}$ & 3.77 & & \\
\hline & $\begin{array}{l}\text { With Doctoral } \\
\text { Degree }\end{array}$ & 3.88 & & \\
\hline \multirow[t]{5}{*}{$\begin{array}{l}\text { Social } \\
\text { Development }\end{array}$} & $\begin{array}{c}\text { With Bachelor's } \\
\text { Degree }\end{array}$ & 3.93 & 0.727 & 0.574 \\
\hline & $\begin{array}{l}\text { With Masters } \\
\text { Units }\end{array}$ & 4.06 & & \\
\hline & $\begin{array}{l}\text { With Master's } \\
\text { Degree }\end{array}$ & 3.99 & & \\
\hline & $\begin{array}{l}\text { With Doctoral } \\
\text { Units }\end{array}$ & 3.73 & & \\
\hline & $\begin{array}{l}\text { With Doctoral } \\
\text { Degree }\end{array}$ & 3.83 & & \\
\hline
\end{tabular}

Table 8 shows the significant difference on the level of improvement of faculty when grouped according to educational attainment, the p-value for impact on level of improvement p-value of.045 which is less than the assumed level of significance of.05. There is no significant evidence to conclude that improvement of faculty have no significant difference when respondents are grouped by highest educational attainment.

It could be deduced that the faculty evaluation by the students have a varying impact on improvement depending on the level of education of the faculty. 


\subsection{Other findings}

The faculty from PUP branches and campuses expressed their thoughts and opinions about student's online evaluation. Faculty recognized that student's on-line evaluation helped them improve and enhance their teaching methods. This is necessary for professional growth of the professors. They said faculty on-line evaluation is good in evaluating the competencies of their professors if students utilize it judiciously. However, they felt that many students do not understand the evaluation and the meaning of its contents. Students seem not to fully understand the questions nor the statements in the instrument. Also, they said that the evaluation instrument is good and well-studied but there should be actions after the data were collected, analyzed, evaluated and published.

Evaluation is good if students speak the truth, but it is terrible if not. Many expressed disappointment that students do evaluation subjectively. Some said that evaluation is not accurate in determining the actual performance of faculty members because most students are not matured enough, especially when they are driven by their emotions. There were faculty who said that the evaluation was being used by abusive students to discredit and take revenge on their professors; unfair for faculty who are doing their job whole-heartedly. Such becomes an opportunity to disrespect them thereby demoralizing the teachers. According to Santoro (2011) demoralization can lead to feeling depressed, discouraged, shameful, and hopeless. In her closer analysis, demoralization is more apt term for some experienced educators who feel that they can no longer do good work. Evaluation has a noble intention, but is does not separate truthful response from vindictive and ill-motive answer.

Some faculty members sensed that students make fun of the evaluation and they didn't take it seriously. According to some faculty, they learned that there were times when only one student answered the evaluation for half of the class. There were students who did not read the contents and there were times when they let other students to do the evaluation for them. They didn't care of the results, too. Yew et al. (2015) said that student evaluation on teaching instruments will be useful and effective for educators depending on the quality of response of students especially if they understand and questions and answer them with honesty.

According to the respondents, it is difficult to get an outstanding rating from those with large number of student evaluators and with too many subject loads. One faculty said that good teachers do not receive good rating when a professor failed the students who do not qualify the course requirements and not because of teacher factor. Carrell 
\& West (2010) found that students reward professors who increase achievement in contemporaneous course but not professors who deep their learning. Receiving an evaluation from the students who are frequently absent is also unfair.

Faculty suggested that student must have a thorough orientation on the purpose of evaluation. They need to pledge before answering the evaluation instrument. They say that students must base their answer on facts and be objective rather than subjective. Students should be more decent in giving bold comments. It was also suggested to require students to write comments. The evaluation must be done with proper monitoring to ensure that only student account holder should do the evaluation. It was also recommended to simplify the content and infuse the OBE concepts in the evaluation instrument.

There are faculty who believed that moral values, behavior and interpersonal relations of the faculty be included in the evaluation instrument. It should also contain the impact of teachers' input on the development of learners. Attendance of the faculty on punctuality, tardiness and absenteeism were also asked to consider.

There are faculty who felt that the use of state-of the-art learning equipment should not be included in the content of evaluation given the fact that they are not available because of budget constraints. The use of technology is dependent upon the subject and there are subjects which are better taught without it.

\section{Conclusion and Recommendation}

The study revealed that generally the student evaluation instrument is applicable to the discipline they are teaching. It is evident in the findings that evaluation helped the faculty in their commitment, knowledge of subject, teaching for independent learning, management of learning as well the personal and social development. Although the evaluation made impact on them in terms of improvement in their profession but there are still much to do to realize the full potential of improvement of the faculty. Dismays were also expressed about the evaluation particularly on the too much freedom of students to discredit their professors. The finding revealed the significant difference on improvement on commitment when respondents were grouped based on educational attainment.

Students should be trained to be more effective evaluators by affirming the purpose of evaluations. Students must learn how to provide meaningful feedback particularly on the written comments. Gathering as much written commentary from students 
would be useful in interpreting numerical data and more likely to pinpoint specific aspects of teaching that would be meritorious or would need improvement.

As findings revealed that faculty assessed themselves improved on personal level, the learning organization must also be introduced so that the institution would likewise benefit from these improvements.

It is also recommended to provide a development program for faculty on how to handle mean spirited or harshly critical student commentary. However, for comments with serious accusations, the dean or the chairperson must investigate the veracity in discreet manner and do reprimand if necessary.

It is about time to simplify the instrument that students could understand the content and this would provide chance to use the OBE concept. It is recommended to have another study on evaluation on the perspective of students.

\section{Author's Note}

Jerielyn V. Reyes - Full time faculty PUP COC DAPR

Arapia C. Ariraya - Full time faculty PUP COC DBC

Reynaldo A. Guerzon -Full time faculty PUP COC DAPR

Aris L. Solis - Full time faculty PUP COC DAPR

The authors wish to extend their gratitude to the following: Polytechnic University of the Philippines through the Office of the Vice President for Research, Extension, and Development for providing funding and technical assistance for the study, to the University Research Evaluation Committee (UREC) for the careful evaluation of the paper, to the Office of the Vice President for Branches and Campuses, the directors of all PuP branches and campuses, and their respective faculty members who provided their support and participation in the completion of the survey, and lastly, to Dr. Erlinda Angeles for extending her expertise in proofreading and language editing.

\section{References}

[1] Alsharif, N. Z., \& Qi, Y. (2014). A three-year study of the impact of instructor attitude, enthusiasm, and teaching style on student learning in a medicinal chemistry course. American Journal of Pharmaceutical Education, 78(7). https://doi.org/10. 5688/ajpe787132 
[2] Buskist, W., Keeley, J., \& Irons, J. (2006). Evaluating and Improving Your Teaching. Retrieved April 15, 2017, from http://www.psychologicalscience.org/observer/ evaluating-and-improving-your-teaching\#.

[3] Carrell, S. E., \& West, J. E. (2010). Does Professor Quality Matter? Evidence from Random Assignment of Students to Professors. Journal of Political Economy, 118(3), 409-432. https://doi.org/10.1086/653808

[4] Chianese, G. (2015). Developing and Assessing Teaching Effectiveness. Procedia Social and Behavioral Sciences, 191, 692-695. https://doi.org/10.1016/j.sbspro.2015. 04.218

[5] Coe, R., Aloisi, C., Higgins, S., \& Major, L. E. (2014). What makes great teaching?: Review of the underpinning research. Retrieved May 23, 2017, from http://www. suttontrust.com/researcharchive/great-teaching/

[6] Frase, L. E., English, F. W., \& Jr., W. K. P. (1995). The Curriculum Management Audit. Lancaster USA: Technomic Publishing Company.

[7] Kelly, M. (2012). Student Evaluations of Teaching Effectiveness: Considerations for Ontario Universities. Retrieved June 11, 2017, from http://cou.on.ca/papers/ student-evaluations-of-teaching-effectiveness/

[8] Merillat, L., \& Scheibmeir, M. (2016). Developing a quality improvement process to optimize faculty success. Journal of Asynchronous Learning Network, 20(3), 159172. Retrieved from http://files.eric.ed.gov/fulltext/EJ1113301.pdf

[9] Murray, H. G. (2005). Student evaluation of teaching: Has it made a difference. In Proceeding of the Annual Meeting of the Society for Teaching and Learning in Higher Education (pp. 1-15). Charlottetown, Prince Edward Island: Society for Teaching and Learning in Higher Education. Retrieved from https://www.stlhe.ca/ wp-content/uploads/2011/07/Student-Evaluation-of-Teaching1.pdf

[10] O'Kell, R. (2017). The problem with annual performance evaluations. Retrieved June 21, 2017, from https://www.universityaffairs.ca/opinion/in-my-opinion/ problem-annual-performance-evaluations/

[11] OSBA. (n.d.). Motivating teachers to improve instruction. Retrieved June 25, 2017, from http://www.osba.org/Resources/Article/Employee_Management/ Motivating_Teachers_to_Improve_Instruction.aspx

[12] Peterson, K. . (1995). Teacher Evaluation: A Comprehensive Guide to New Directions and Practices. USA: Corwin Press Inc. Santoro, D. a. (2011). Good Teaching in Difficult Times: Demoralization in the Pursuit of Good Work. American Journal of Education, 118(1), 1-23. https://doi.org/10.1086/662010 
[13] Stark, P., \& Freishtat, R. (2014). An Evaluation of Course Evaluations. ScienceOpen Research, (September), 1-26. https://doi.org/10.14293/S2199-1006.1. SOR-EDU.AOFRQA.v1

[14] Taylor, E., \& Tyler, J. (2012). The Effect of Evaluation on Teacher Performance. American Economic Review, 102(7), 3628-3651. https://doi.org/10.1257/aer.102.7. 3628

[15] Yew, T. M., Kanaki, F. D., Manickam, K., Jen, L. S., \& Hoay, K. C. (2015). Designing an Instrument for Providing Better Student Feedback on Teaching Effectiveness. Malaysian Online Journal of Educational Sciences, 3(1), 14-22. Retrieved from http://search.ebscohost.com/login.aspx?direct=true\&db= eric\&AN=E)1086260\&site=ehost-live 